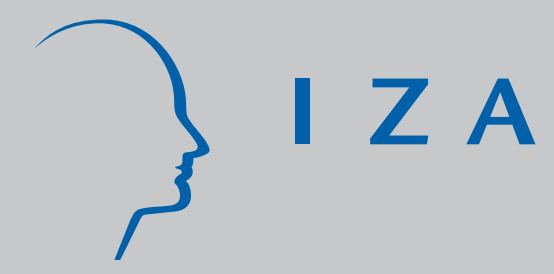

IZA DP No. 2486

Rural People's Perception of Poverty in China

Bj orn Gustafsson

Ximing Yue

December 2006 


\title{
Rural People's Perception of Poverty in China
}

\author{
Bjorn Gustafsson \\ University of Göteborg \\ and IZA Bonn \\ Ximing Yue \\ Renmin University of China
}

\section{Discussion Paper No. 2486 \\ December 2006}

\author{
IZA \\ P.O. Box 7240 \\ 53072 Bonn \\ Germany \\ Phone: +49-228-3894-0 \\ Fax: +49-228-3894-180 \\ E-mail: iza@iza.org
}

\begin{abstract}
Any opinions expressed here are those of the author(s) and not those of the institute. Research disseminated by IZA may include views on policy, but the institute itself takes no institutional policy positions.
\end{abstract}

The Institute for the Study of Labor (IZA) in Bonn is a local and virtual international research center and a place of communication between science, politics and business. IZA is an independent nonprofit company supported by Deutsche Post World Net. The center is associated with the University of Bonn and offers a stimulating research environment through its research networks, research support, and visitors and doctoral programs. IZA engages in (i) original and internationally competitive research in all fields of labor economics, (ii) development of policy concepts, and (iii) dissemination of research results and concepts to the interested public.

IZA Discussion Papers often represent preliminary work and are circulated to encourage discussion. Citation of such a paper should account for its provisional character. A revised version may be available directly from the author. 
IZA Discussion Paper No. 2486

December 2006

\section{ABSTRACT}

\section{Rural People's Perception of Poverty in China*}

Subjective Poverty Line methodology is applied to rural China 2002 using a sample from 22 provinces. Respondents were asked two questions: one on amount of food necessary and another on amount of cash necessary for their households. The respondent's perception of how much cash is needed varies profoundly and positively by income in the county where the respondent lives. The findings provide an argument for increasing the official poverty line for China as average household income increases. Poverty in rural China is disproportionally concentrated to the western regions and to poor counties. Most of rural China's poverty can be attributed to households living outside classified poor areas. People living in a household with many members, those with a household head with a short education, and children face higher poverty risks than other persons.

JEL Classification: $\quad$ 132, O15, P36

Keywords: China, poverty, poverty line

Corresponding author:

Bjorn Gustafsson

Department of Social Work

University of Göteborg

P.O. Box 720

SE 40530 Göteborg

Sweden

E-mail: Bjorn.Gustafsson@socwork.gu.se

\footnotetext{
* We acknowledge grants from the Swedish International Development Cooperation Agency (SIDA) and the Ford Foundation for funding the collection of the data uses for this study. Ximing Yue acknowledges funding from Ford Foundation, Beijing office enabling him to spend one academic year at University of Western Ontario during which part of this research was carried out.
} 


\section{Introduction}

The substantial reduction of rural poverty has often been hailed as a major achievement of reform China, yet this process has been uneven across time and space (Ravallion and Chen 2004). Much progress took place during the beginning of the 80s, though knowledge of the extent of poverty during the planning period is limited; real progress might actually have been larger than what official figures indicate (Yao, 2000). In contrast to the significant poverty reduction following the first reforms, certain studies using large sample surveys report little poverty reduction in rural areas between 1988 and 1995 except for the eastern regions of the country (Gustafsson and Wei, 2000, Khan and Riskin, 2001). However, this spell was followed by one of rapid poverty reduction across the entire country as reported in Khan (2006), who compares the years 1995 and 2002. The episodes of reduced poverty in rural China are in contrast to the development in urban China. There, marketisation has increased vulnerability as people have lost their jobs and poverty has surfaced (Fang et al 2002, Meng et al 2005, Li and Sato, 2006, Knight and Li 2006). In addition, the massive inflow of rural residents without a hukou has increased the poverty problem in urban China; many such persons live under conditions at least as bad as among the poorest members of the registered population.

Despite considerable progress in rural poverty reduction in the past, and Chinese poverty becoming more urbanized, rural poverty remains a serious issue in contemporary China. Assessments vary widely on the extent of poverty in present day China, however. According to the World Development Report 2005 from the World Bank, 16.6 percent of China's population were poor in 2001. This means a poverty population of approximately 216 million persons; by this assessment China has the world's second largest poverty population (Chen and Ravallion 2004). In contrast, according to estimates from the National Bureau of Statistics (NBS), China's rural poverty population for the same year consists of 29.27 million persons with a poverty rate of 3.2 percent. Important reasons for the discrepancy in assessments are the different choices of economic resources considered when making the assessment as well as at what level the poverty line is set. Regarding the former, it can be noted that the World Bank bases its assessment on the household's consumption, while information on income would imply a lower poverty rate. Another reason is the height of the poverty line. 
The World Bank's poverty line of 1 USD PPP per person and day is above the poverty line applied by NBS; in 2002, 878 Yuan per person and year compared to 627 Yuan per person and year, respectively, a difference of not less than 40 percent of the lower alternative. Though applying the low poverty line of NBS could have been justified previously, this appears less defendable when China has moved from being considered a low-income country to a lower middle-income country. Evidence indicates that across countries there is a positive relation between the income level of the country and the height of the poverty line (Ravallion et al, 1991). Further, there are many examples from industrialised countries where poverty lines are adjusted upwards as income of the population grows. For example, Eurostat reports figures on the risk of poverty in the member states of the European Union based on poverty lines specific for each country; these poverty lines change in conjunction with median incomes. That is, when median income rises the purchasing power of the poverty line rises. With this background it is not surprising that NBS, in addition to reporting poverty statistics, has also started to publish statistical information on people in rural China below a "lowincome standard”. This low-income standard was 869 Yuan per person and year in 2002, almost identical to 1 USD PPP per day and person. Is such a move towards a higher poverty line justified from the perspective of assessments made by people living in China? Answering this question is the first task of this paper.

The exchange of ideas and opinions on how to define a poverty line often tends to be a conversation between experts. There is a long tradition in poverty research to base poverty assessments on input of budget standards, for example. However, the alternative of using people's perceptions on income adequacy as input when constructing a poverty line also exists. People can be asked different questions in different ways. Here we follow the methodology of the Subjective Poverty Line (SPL) according to which respondents are asked to assess how much income is needed for their own household. Typically, such responses are positively related to the income of the respondent. This relation is uncovered by the analyst and based on such a response function, the poverty line is obtained.

Most applications of the SPL approach have been carried out for industrialised countries. ${ }^{1}$ In contrast to the case of industrialised countries as well as urban China, a large part of people’s

\footnotetext{
${ }^{1}$ Early examples of studies of countries in the European Union are van Praag et al. (1982) and Hagennaars (1986). For studies on the United States see for example Colasanto et al. (1984), Danziger et al. (1984) and more recently Garner and Short (2003). Pradan and Ravalion (2000) is a rare example from the developing world. For
} 
consumption in rural China consists of self-produced food, although transactions using money are becoming more prevalent. This is the background for why our application of the SPL approach for defining a poverty line is modified. Respondents were asked to estimate not only how much cash was necessary for their household, but also how much grain.

The second task of this paper is to investigate how such assessments are related to income of the place (the county) where the respondent lives. We hypothesise that assessment on money necessary is positively related to income of the county while this is much less true for assessment on food needed. Results from this investigation could shed light on the longstanding question of whether poverty should be conceptualised as absolute, relative, or having elements of both. China provides a solid basis for such an investigation as it is a large country with a rather large variation in mean income across locations.

Applying the SPL approach to rural China can also address the issue of what equivalence scales should be used in poverty assessments for China, our third task. Poverty assessments in industrialised countries typically use equivalence scales indicating considerable economies of scale in the households, and where expenditure needs of children depend on the age of the child. Seen from such a perspective, the official Chinese approach to poverty line specification appears "primitive” as expenditure needs are assumed to be strictly proportional to the number of household members and there is no adjustment for the age of the person. Such a practice can be justifiable in an economy where most of the expenditure needs covered in the poverty line are for food. However, in industrialised countries food consumption makes up only a small part of total expenditure needs. There is a much larger scope for economies of scale in non-food consumption as some goods, such as a TV set or a car have the character of a household public good.

For this study we use large surveys made for large regions of China in 2002 to derive Subjective Poverty Lines. We argue that for some purposes it makes sense to construct poverty lines that are province specific. As our fourth and final task we use the derived poverty lines for portraying rural poverty to show how location as well as household characteristics affects the risk of being poor.

China, Gustafsson et al (2004) applied the approach to a sample taken from 12 cities in 1999. Cross-country comparisons using SPL are found in Saunders et al (1994) and Garner and de Vos (1995). 
The rest of the paper is laid out as follows: In the next section we present the SPL methodology and discuss considerations when applying it. Our data is described in Section 3, while Section 4 presents results on how people's answers to the questions are affected by household location and characteristics. Section 5 reports the findings on the poverty profile for rural China in 2002, and finally Section 6 summarises the study.

\section{The subjective poverty line approach and its application}

The SPL offers a simplified procedure for deriving a poverty line, needs little data and constitutes an alternative to approaches traditionally used. An SPL is the outcome of what people think, and can thus be thought of as more democratic than basing the poverty line on an expert's assessments. The idea that people have a direct say on the determination of the poverty line has a certain appeal.

However, it should also be mentioned that in the real world, countries determine their poverty lines through the political process. This determination takes place in an environment where governments have to consider many expenditure needs when levying taxes. It is impossible for a government to fulfil all expectations from the population that put pressure on the public coffers. Thus one would not be surprised if a derived SPL were higher than the poverty lines applied by the government. The role of the SPL is perhaps not so much to replace the political process for determining a poverty line, but rather to contribute with one input in such a process.

In the SPL approach respondents are required to evaluate the situation of their own households, not a hypothetical household. This is attractive as it could be difficult to evaluate expenditure needs of households with other attributes. Within this method various questions can be used. One frequently used question is the Minimum Income Question (MIQ) which asks for the monetary amounts people consider to be the minimum necessary for supporting their household. We have taken this as a point of departure but modified the approach by asking two questions instead of one. First, we asked for the physical amount of grain necessary for the household. Second we asked how much cash is needed to maintain the 
household (disregarding grain). ${ }^{2}$ The SPL for rural China is obtained adding these two components (after having transformed the answers to the first question into cash).

Goedhart et al (1977) introduced the intersection method, which makes it possible to derive a poverty line from the responses. The thresholds are calculated as the income level where $Y_{\text {min }}$ respectively $G_{\min }$ equals $Y$ given the relationships:

$$
\begin{aligned}
& \log \left(G_{\text {min }}\right)=a_{0}+a_{1} \log (Y) \\
& \log \left(Y_{\min }\right)=b_{0}+b_{1} \log (Y)
\end{aligned}
$$

$G_{\min }$ is the respondent's minimum physical amount of grain response, $Y_{\min }$ denotes the respondent's minimum cash response, and $\mathrm{Y}$ is current household income. $\mathrm{a}_{0}$ and $\mathrm{b}_{0}$ are positive numbers, and $a_{1}$ a positive number less than 1 (as is $b_{1}$ but we hypothesise the former to be considerably smaller, see Figure 1). As it is believed that only persons with actual incomes equal to the stated minimum income necessary have a realistic view of the minimum level, the intersections where $Y_{\min }$ and $G_{\min }$ equals $Y$ are chosen for the two components of the poverty line.

/Figure 1 about here/

The answer to the minimum income question can also depend on attributes of the household other than income such as family size, the age of household members, and the location of the household. The location of the household can in turn be characterised by its attributes. A rationale for considering location is that people form their expectations based on how their neighbours, local friends and relatives fare; these individuals make up a reference group. The local attribute we will consider here is the mean income of the county where the respondent resides; we expect to find a positive influence from it on cash assessed to be needed by the respondent. We have no conjecture on a possible existence and in such case sign of a relation

\footnotetext{
${ }^{2}$ The two questions asked in Chinese are: "1, weile quanjia nenggou tuopin, qing guji ninjia quannian zhishao xuyao duoshao kouliang,__gongjin.” "2. weile quanjia nenggou tuopin, zai manzu kouliang xuyao zhiwai, qing guji ninjia quannian zhishao hai xuyao duoshao xianjin _ _ yuan.” The translation is as follows: ”1. Please estimate the minimum amount of food grain needed to sustain the household for a year: estimate the minimum amount of cash needed to sustain the household for a year: Yuan.” kg." "2. Please
} 
between income of the county and grain perceived as needed. ${ }^{3}$ We can now rewrite equations (1) and (2) as:

$$
\begin{aligned}
& \log \left(G_{\text {min }}\right)=a_{0}+a_{1} \log (Y)+a_{2} X_{i}+a_{3} \log (H) \\
& \log \left(Y_{\min }\right)=b_{0}+b_{1} \log (Y)+b_{2} X_{i}+b_{3} \log (H)
\end{aligned}
$$

$\mathrm{X}_{\mathrm{i}}$ are the variables representing household attributes other than household income that are related to answers to the questions and $\mathrm{H}$ is the mean income of the county where the respondent lives. After estimating the response functions (3) and (4), the two components of the subjective poverty lines are derived assuming $\log \left(\mathrm{G}_{\mathrm{min}}\right)=\log (\mathrm{Y})$ as well as $\log \left(\mathrm{Y}_{\min }\right)=$ $\log (\mathrm{Y})$ :

$$
\begin{aligned}
& \log (S P L)_{g}=Y_{\min } *=\left[a_{0}+a_{2} X+a_{3} \log (H)\right] /\left(1-a_{1}\right) \\
& \log (S P L)_{m}=Y_{\min } *=\left[b_{0}+b_{2} X+b_{3} \log (H)\right] /\left(1-b_{1}\right)
\end{aligned}
$$

In this formulation both components of the poverty line are allowed to vary by income of the county in which the respondent resides.

As SPL has gained in uses, certain methodological issues have been discussed by researchers (see Kapteyn et al. (1988) and Garner and de Vos (1995)). One theme is how to phrase questions to respondents and how to interpret the answers. Survey practitioners are well aware that slight changes in wording a question can influence responses greatly. Often it is difficult for the survey constructor to know well how a respondent comprehends a particular sentence and a particular concept.

Our application is based on the presumption that respondents can distinguish between need of grain and need of cash, where the latter covers expenditures for daily living though not such infrequent outlays as housing repairs or medical treatment in a hospital. The view of which expenditures respondents have in mind is important as it influences the definition of income the analyst applies when estimating response functions. While economists typically prefer a

\footnotetext{
${ }^{3}$ It could actually be a negative relation as is the case when more costly food is substituted for grain in higher income counties.
} 
comprehensive income concept that includes rents from owner occupied housing, for example, we argue that it makes better sense to exclude this component for the definition of total income when estimating a response function

A second methodological theme concerns which attributes the analyst should include in the response function. One group of variables can be motivated by needs as the following examples show: Small children need less food than other persons. In rural China parents have to pay school fees for their youngsters. People living in cold climates need more money for heating than their counterparts living in warmer climates. Disabled and sick people can have expenditure needs not found among the healthy. Another group of variables to include in the response function can be motivated by cost differences. Consumer prices often vary by location. Finally, there are arguments of aspiration and reference group. Individuals' views are formed in their social relations. In present-day rural China this often means from interaction with others in the village or in areas surrounding it. Therefore we expect to find a positive relation between mean income of the county and a person's response to the questions on cash income needed. In our application we consider age of the person, which can indicate a difference in need though not disability status.

A third methodological and to some degree conceptual theme when applying SPL concerns how to move from the estimated response function to defining a poverty line. Which attributes of a household should the poverty line consider? Estimating a response function can be seen as a purely academic exercise. A poverty line needs to function in a social reality, however. While an estimated response function can indicate that gender and high age affect household responses, enabling a poverty line to differ by such attributes is not acceptable in many social situations.

When constructing a poverty line there is also the conceptual issue of which territory the poverty line should cover, an issue not specific to the SPL approach. When assessing poverty in rural China, NBS uses a poverty line thought to represent the same purchasing power for all of the country ${ }^{4}$. Clearly, this is not the only alternative. Much policymaking in China is made at the provincial level, which would justify poverty lines specific for each province. The

\footnotetext{
${ }^{4}$ According to publications from NBS, the thresholds vary by province in order to consider differences in consumer prices across provinces. The details are not reported in publicised documents and only the national average (for example 627 for 2002) is published.
} 
motive for variation in poverty lines across provinces is not differences in consumer prices, but differences in income. High-income provinces could afford higher poverty lines than low income provinces. ${ }^{5}$

\section{Data}

The data for this study comes from the rural household surveys conducted in the spring of 2003 for the year 2002 by the research project "Income Distribution, Growth and Public Policy in China” involving a group of researchers at the Institute of Economics, Chinese Academy of Social Sciences, Beijing and scholars from other countries. The project was assisted by the General Team of Rural Surveys at the National Bureau of Statistics (NSB) that conducted the fieldwork in early 2003. The questionnaires were designed by the project team to meet the needs of research.

The sample was drawn from the large sample used by NBS in its annual household survey covering around 67000 households. This sample is selected in a multi-age procedure to be representative at the province level and each province statistical bureau is responsible for samples at the village level. At the village level a probability sample of ten households is selected. The rural households are asked to keep detailed records of their expenditures as well as provide information on their income. A large number of assistant enumerators assist the households in keeping good accounts and in checking the information.

For the research project a sample of 9200 households with 37969 individuals were sampled from the larger sample used by NBS. This sample covers 22 provinces or provincial level units of China: Beijing, Hebei, Shanxi, Liaoning, Jilin, Jiangsu, Zhejiang, Anhui, Jiangxi, Shandong, Henan, Hubei, Hunan, Guangdong, Guanxi, Chongqing, Sichuan, Guizhou, Yunnan, Shaanxi, Gansu and Xinjiang. The sampled households live in 120 different counties. The questionnaire was designed to derive disposable income according to international standards, and the sampled households were also asked questions regarding income in kind. ${ }^{6}$ Our working sample for estimating the response functions reported in the

\footnotetext{
${ }^{5}$ For the sake of argument, there is no reason to stop at the province level; there is also policymaking made at the sub-province level and one could imagine poverty lines defined on prefecture or county level. However, for this study our data precludes such alternatives.

${ }^{6}$ For more details on the survey see Li et al (2006).
} 
next section consists of 6853 households from which meaningful answers to the Minimum Income Questions were obtained. We use the entire sample when deriving results on the extent and profile of poverty (Section 6).

\title{
4 Response functions, poverty lines and equivalence scales
}

\author{
/Table 1 about here/
}

Table 1 reports estimated response functions. The first dependent variable is (the log of) the answer to the question of physical amount of grain, the second a transformation into cash. Our derivation of the second variable from the first is provided in Appendix 1 and in most cases the results, as expected, are rather similar. The third variable is the log of cash needed. In an alternative specification, reported in Appendix 2, dummies for provinces were added to the specification and in the text we comment on both results. We use a specification that includes variables for the number of household members, as well as number of young children, school age children and elderly persons. The results are rich and indicate that the derived SPL has several interesting properties: One is that it differs by income of county where the respondent lives. Another is that the threshold for a particular family depends on the number of household members in a non-linear way, but also to some extent on the age of household members.

A first comment is that, as expected, assessment on need for cash is positively related to household income for both specifications, and the t-statistics are fairly high. In contrast the positive relation between household income and grain is much smaller, and in the alternative specification (reported in Appendix 2) the coefficient is estimated with a low t-statistic.

A second finding is that some of the coefficients for the number of persons of a particular age are significant, while others are not. We find the coefficients for the number of household members being elderly in the latter group. In contrast, the coefficient for the variable indicating the number of children under age 7 in the equation for need of grain is negative, indicating that small children are considered to have lower nutrition requirements than other persons. The corresponding coefficient in the equation for cash needed is also negative, but relatively small and significant only at the 6-percent level. In contrast, we report a positive coefficient for the number of school children in the equation for cash assessed necessary. It 
indicates that cash necessary for a household of four members increases by 8 percent, or 148 yuan. ${ }^{7}$ This should be interpreted from the background that households in rural China typically pay school fees. ${ }^{8}$ We report a positive effect of minority status in the function for money needed, but in the alternative specification this coefficient is estimated with a low tstatistic.

A third comment is that effects of log county income affect cash needed positively as the coefficient is estimated with a high t-statistic in Table 1. Still the coefficient is positive when provincial dummies are added to the specification and the t-statistic is above 2 . However, the magnitude for the coefficient decreases, probably indicating that perceptions of money needed are not solely shaped within the county, but also in a wider sub-national environment. Similar results for grain needed are not found. This is further illustrated in Table 2 where we predict the two components of the SPL for an adult person living in households of various sizes in counties with different mean incomes as observed in the survey.

\section{/Table 2 about here/}

Reading Table 2 we see that perceived needs for grain are only weakly related to county income. For example, if we compare a household of four adult members living in the county at the top five percentile of counties (the 95th percentile), according to average income of the county with the one living in the county belonging to the bottom five percent the estimated need for grain decrease by not more than 6 percent. Compare this with an increased perceived need for money of not less than 72 percent. The latter clearly illustrates how different rural people estimate needs for cash depending on where they reside. The lowest (on a per capita basis) perceived need is for a large family size in the county situated at the lowest 5 percent of the distribution of county income, 858 Yuan. This is very close to the low-income line applied by NBS.

\section{/Table 3 about here/}

\footnotetext{
${ }^{7}$ The numbers are obtained by comparing a majority household of three adults and one school child and another household with four adult members. The households are assumed to reside in a county with median income of county income per capita.

${ }^{8}$ The argument that poverty assessment for rural China should be sensitive to the household's expenditures on education and health care is also put forward in Gustafsson and Li (2004).
} 
Perceived expenditure needs per person fall very rapidly between households having one and two members. This is also shown in Table 3 which expresses how perceived needs for grain (in cash), cash and the sum of the two components differ by the number of household members using the needs for a one-person household as unit. That is, we report the equivalence scale implied in the response function. The considerable economies of scale perceived when comparing households with one and two members is visible in need of money income but actually also for need of grain. Both needs might actually provide the reason why we observe so few one-person households in rural China; people choose to live together in order to economise. Looking more in detail at Table 3, we find that expenditure needs for a marginal household member are 0.7 when moving from a two-person household to a threeperson household, 0.6 when moving from a four-person household to five-person household, and continues to decrease somewhat with increase in household size. Interestingly enough, these numbers are relatively similar to the numbers implied in the "OECD equivalence scale" and the "modified OECD equivalence scale. ${ }^{9}$

As is true for all who estimate poverty based on the SPL approach, we now have to decide how to move from the response function to the poverty line used. ${ }^{10}$ We have found clear results that household size and expenditure needs are related in a non-linear way and also that place of household matters. We therefore decide to allow our poverty lines to have such properties. In order to simplify the poverty line, we decide not to consider age in our poverty assessment, although we have found reasons to support this as reported above. Regarding allowing the poverty line to differ by location, there are also various alternatives to choose from. We choose to extract median county income for each province from our data and to derive poverty lines that are conditioned for which province a particular household resides in. People in high-income provinces are thus considered to need higher purchasing power than their peers in low-income provinces, due to income of the reference group not differences in living costs. ${ }^{11}$

\footnotetext{
${ }^{9}$ The former assumed equivalence values of 0.7 for adults and 0.5 for children, the latter 0.5 for adults and 0.3 for children, see OECD (2005).

${ }^{10}$ Sensitivity analyses indicate that most of the results reported in the next section are robust with respect to the choices we made.

${ }^{11}$ Brandt and Holz (2006) present provincial price index for rural China based on costs for a given basket. When we regress our SPL as presented in Table 4 on the provincial prices the coefficient for the price level is estimated with a rather low t-statistics.
} 
Table 4 shows considerable variation in our poverty lines across China's provinces included in the sample. As our poverty line differs by household size, for simplicity Table 4 shows the average amount per person using the actual distribution of households size in our data for each province. The highest poverty line 1741 is for Zheijang the lowest for Guizhou 1 016, a difference of 71 percent for the latter. The SPL developed around the median county income (and mean household size) in Guizhou is actually 17 percent higher than the low-income standard used by NBS. SPLs developed around provincial county median income in the other 22 province or province units in our sample are all higher. From this we can conclude that the low-income line applied by NBS fits people's perceptions of minimum income better than the official poverth line, but is still lower than peoples perceptions particularly for households in the high-income provinces.

\section{The extent and profile of rural poverty $2002^{12}$}

How does rural poverty in China 2002 appear if we apply the derived SPL? We proceed in two steps: The first is to report descriptive results, the second to estimate Probit models. Table 5 shows how the extent of poverty differs by spatial characteristics such as province, region (the three regions East, Central and West), as well as the division poor counties, non-poor counties, ethnic minority and majority group. For each category we measure poverty using the family of indices suggested by Foster, Greer and Thorbecke (1984). ${ }^{13}$ In this section the individual is the unit of analysis. That is, we assign all members of a household the status of being poor or not poor depending on income of the household. ${ }^{14}$

\footnotetext{
${ }^{12}$ Khan (2006) uses the same sample as we use together with a companion sample of urban China 2002 and earlier similar samples for 1995 to monitor the development of poverty. He applies two alternative poverty lines for rural China based on a food energy requirement: 876 Yuan per person and year and 1252 Yuan per person and year. The lower alternative is more or less identical to the "low income" standard applied by NBS and 1 USD PPP and day. Our results confirm that poverty varies by province and province mean income and inequality in province income. In addition it shows how poverty varies by poor county / non-poor county, ethnic status, age of the individual, education of household head and household size.

${ }^{13}$ This family of indices gives weight to the proportions of persons falling below the poverty line by the size of the gap between income and poverty line. In this application we set the weight equal to 0,1 , and 2 and arrive at the poverty rate, the poverty gap index and the poverty gap squared. When computing the index, a few observations with negative total incomes had their incomes set to zero.

${ }^{14}$ A comparison with official statistics makes it possible to compare our sample with information from Census 2000 regarding distribution of variables region (central, west and east), poor area and non-poor area and ethnic minority / ethnic majority, and certain differences are evident. Therefore we use sample weight derived from the Census when we report the composition of poverty disaggregated after those variables.
} 
When applying our poverty lines, we arrive at a poverty rate for rural China 2002 of 15.3 percent, see Table 5. This is a poverty rate that is surprisingly close to the rate of 16.6 percent the World Bank reports for China as a whole in 2001, an estimate that is based on a lower poverty line but is applied to the consumption of the household. There is a very large crossprovince variation in the extent of rural poverty although the exact ranking of provinces differ somewhat by poverty index; it should be remembered that the breakdown at the province level leads to small samples. Provinces with little rural poverty are Guangdong, Jiangsu and Beijing with poverty rates below 4 percent, and at the other end of the spectrum we find Guizhou, Ganzu, Shaanxi, Shanxi and Yunnan with poverty rates over 20 percent and in some cases even higher. ${ }^{15}$ When aggregating the provinces into the three regions East, Central and West we find, as expected, that poverty is most extensive in the western region with a poverty rate of 21 percent, and is less pronounced in the eastern region, where the poverty rate is 10 percent. However, of the three regions, the western region has the smallest total population whereas most of China's poor live in regions other than the Western, see the last three columns of Table 5 which show the composition of poverty.

Central to fighting poverty in rural China is the channelling of resources to areas that are designated as poor (see for example Park et al, 2002). The results reported in Table 5 show as expected that poverty is more extensive in the poor areas than elsewhere. Still a poverty rate of 31 percent means that most persons living in poor areas are not considered poor. As the present policy does not emphasise income differences across households within the poor areas, our results imply that many resources for poverty alleviation will leak out to non-poor households and their members. Another limitation with the present policy of targeting resources to designated poor areas is that a large part of China's rural poverty is located outside these areas (see Riskin, 1994). We find that at least half of China's rural poverty is located outside poor areas (the proportion varies between 55 and 64 percent depending on index). Taking the findings together, we suggest that the policy of geographically targeting poor areas has quantitatively important shortcomings of both not reaching many of the poor (undercoverage) as well as benefiting many that are not poor (leakage). The last part of Table

\footnotetext{
${ }^{15}$ Guizhouo and Ganzu have the highest poverty rates, over 30 percent, but Shanxi and Yunnan score highest when inspecting the poverty gap squared index, indicating that for the latter, poverty is deeper among the poor in the sample for those provinces.
} 
5 shows that people belonging to ethnic minorities are reported to be more poverty prone than the ethnic majority. However, as the latter are more numerous, the typical poor person in China belongs to the majority population.

/Table 6 about here/

Table 6 reports poverty by age of person, number of household members and education of household head. According to all three indices, young children are more poverty prone than people of other ages. However, rural China is inhabited by few young children so less than 10 percent of rural poverty in China can be attributed to young children; even when adding school children we find that not more than one out of five poor people in rural China is a child. It is interesting to see that although poverty indices are higher for the elderly than for adults of other ages, the difference is small. Rural poverty in China is thus very much a problem for people in work active ages.

Turning to number of household members, we report the highest poverty indices for the largest household size, eight and more persons. However, there are few such households in the population so most poverty is found in households of more moderate size. Actually, more than half of all poverty can be found in households with four or five members. In the final breakdown we can see a tendency for a negative relation between education of household head and poverty.

\section{/Table 7 about here/}

In the second step to understanding the problem of poverty in rural China we estimate a probit model with the poverty status as the dependent variable. Table 7 reports estimates using specifications that differ in how we introduce spatial variables. For all three specifications we report coefficients for age meaning that poverty risks diminish with age of person, but at a declining rate. The poverty risk also diminishes with education of household head and according to the first two specifications, it increases with household size. Minority status is not found to significantly affect the poverty risk in the specification where we use dummies for province. As could be expected from Table 5, in the first specification there are large effects of province on the poverty risk. This is further illustrated in Figure 2 where we predict the probability of being poor for two typical households living in each of the 22 province- 
level units in the sample. Generally poverty risks are higher when living in the West than in the East. For example, a six-person household headed by a person 30 years of age with six years of education is predicted to have a poverty risk as high as 39 percent if living in Ganzu, but only of 3 percent if living in Jiangsu. However, there are also exceptions from this pattern as the predicted poverty risk is higher in Liaoning (in the eastern region) than in Sizhuan (in the western region).

/Figure 2 about here/

In the second specification reported in Table 7 we replace the province dummies with the logarithm of mean income per capita of the rural part of the province and the Gini for household income of the province; both variables are computed from the data. The coefficient for mean income is negative, that of the Gini coefficient positive and both have high t-values. In the third and final specification we add a dummy for poor area; we find a positive coefficient for the variable and that the coefficient for mean income reduces somewhat. We can thus conclude that location greatly contributes to the risk of being poor in rural China: the provincial variation can be traced back to differences in mean income and the distribution of income across the provinces and that location in a poor area aggravates the poverty risk.

\section{Conclusions}

In this paper we have investigated rural people's perceptions of poverty by analysing questions on income adequacy using samples covering large parts of China for 2002. In one question people were asked to indicate grain needed for their household and in the other to indicate cash needed. By estimating response functions we could derive two components for a Subjective Poverty Line.

A first conclusion from the exercise is that the low-income line of NBS is closer to rural people's perceptions of income adequacy than the NBS poverty line. However, the lowincome line of NBS is still lower than a SLP derived from assumptions on location and number of household members. Only for a rather large household from a county having a fairly low income is the SPL similar to the low-income line of NBS. 
A second conclusion is that people's perceptions of income adequacy are strongly affected by mean income in the county where they live. People in high-income counties perceive more cash is needed than those living in low-income counties. This variation in perception by income in the cross sections is an argument for increasing the official poverty line as well as the low-income threshold as Chinese households are getting richer. It appears that poverty to a large extent is relative when it comes to need of cash, less so when it comes to need of basic food. The response functions we have estimated indicate that people conceptualise poverty both as absolute and as relative. It is approximately absolute in needs for grain, relative for cash. This is probably not unique to location and time of the survey.

The poverty line and the low-income line for rural China constitute numbers to be multiplied by the number of household members. This number does not vary by the number of household members nor by the age of the persons in the households. The third conclusion of our exercise is that rural Chinese households have more sophisticated views of such matters. According to people's perceptions, young children need less grain than adults, but a school child incurs more money expenditures than an adult. The latter probably reflects the school fees Chinese households have to pay. In addition, households perceive that economies of scale exist. This is particularly important when assessing needs for households with few members. There are thus arguments for statistical authorities in China to improve the construction of the poverty line. This argument increases in force as households become smaller in size over time.

Our results on rural China's poverty profile 2002 show poverty to have a profound spatial character. People in the western regions are more poverty prone than those living in the eastern region. Not surprisingly, people living in officially classified poor areas are more likely to be poor than those living elsewhere. More interesting perhaps is that according to our results, most people in poor counties are not considered to be poor according to our poverty line. Furthermore, at least half of China's rural poverty is located outside the poor areas. This speaks for policy changes to geographically target measures more closely. We also found that the risk of being poor in rural China decreases by age of person and education of household head. Most of the rural poor in China are in work active ages. However, small children face poverty risks higher then for people of other ages. 


\section{References}

Brandt, L and Holz, C. (2006) "Spatial Price Differences in China: Estimates and Implications”, Economic Development and Cultural Change, 55, 43- 86.

Chen, S and Ravalion, M. (2004) "How Did the World's Poorest Fare since the Early 1980s", World Bank Research Observer, 19 (2) 141 - 169.

Colasanto, Diane, Kapteyn, Arie and van der Gaag, Jacques (1984) “ Two Subjective Definitions of Poverty. Results from the Wisconsin Basic Needs Study”, Journal of Human Resources, 19, 127 - 138.

Danziger, S., van der Gaag, J, Smolensky, E and Taussing, M. (1984) “The Direct Measurement of Welfare Levels: How Much Does It Take to Make Ends Meet“, Review of Economics and Statistics, 66, $500-505$.

Fang, Cheng, Zhang, Xiaobo and Fan, Shenggen (2002) "Emergence of Urban Poverty and Inequality in China: Evidence from Household Survey”, China Economic Review, 13, 430 443.

Foster, J., Greer, J. and Thorbecke, E. (1984) "A Class of Decomposable Poverty Measures", Econometrica, 52, 761 - 766.

Garner, Thesia I. and Short Kathleen S. (2003) "Personal Assessments of Minimum Income and Expenses: What do They Tell Us About 'Minimum Living' Thresholds and Equivalence Scales?”, pages 191 - 243 in Inequality, Welfare and Poverty: Theory and Measurement, vol 9, Elsiver.

Garner, Thesia I. and de Vos, Klaas (1995) “Income Sufficiency v. Poverty. Results from the United States and The Netherlands”, Journal of Population Economics, 8, 117 - 134.

Goedhart, Theo, Halberstadt, Kapteyn, Arie and van Praag, Bernard (1977) “The Poverty

Line: Concepts and Measurement”, Journal of Human Resources, 12, 503 - 520.

Gustafsson, Björn and Wei, Zhong (2000) "How and Why has Poverty in China Changed? A Study based on Microdata for 1988 and 1995”, China Quarterly, 164, 983 - 1006.

Gustafsson, Björn and Li, Shi (2004) "Expenditures on Education and Health Care and Poverty in Rural China”, China Economic Review, 15, 292 - 301.

Gustafsson, Björn, Li, Shi and Sato, Hiroshi. (2004) “Can a Subjective Poverty Line be Applied to China? Assessing Poverty among Urban Residents in 1999”, Journal of International Development, 16, 1089 - 1107.

Hagenaars, Alid J.M. (1986) The Perception of Poverty Amsterdam: North Holland.

Khan, Azizur. R. (2006) “Growth, Inequality and Poverty. A Comparative Study of Chin’s Experience in the Periods Before and After the Asian Crisis” in Gustafsson, Björn. Li, Shi and Sicular, Terry. (Eds) Inequality and Public Policy in China, Cambridge: Cambridge University Press. (Forthcomming) 
Khan, Azizur Rahman and Riskin, Carl (2001) Inequality and Poverty in China at the Age of Globalization, Oxford: Oxford University Press.

Kapteyn, A., Kooreman, P. and Willemse, R. (1988) "Some Methodological Issues in the Implementation of Subjective Poverty Definitions”, Journal of Human Resources, 23: 222 242.

Knight, J. and Li, Shi (2006) “Three Poverties in Urban China”, Review of Development Economics, 10 (3), $367-387$.

Li, Shi and Sato, Hiroshi (Eds) (2006) Unemployment, Inequality and Poverty in Urban China, Routledge Curzon.

Meng, X., Gregory, B. and Wang, Y (2005) "Poverty, Inequality and Growth in Urban China 1986 - 2000”, Journal of Comparative Economics, 33 (4), 710 - 729.

OECD (2005), 'What are Equivalence Scales?' September. downloadable as http://www.oecd.org/dataoecd/61/52/35411111.pdf.

Park, Albert, Wang, Sangui and Wu, Guobao (2002), "Regional Poverty Targeting in China “, Journal of Public Economics, 86, 123 - 157.

Pradhan, Menno and Ravallion, Martin (2000) "Measuring Poverty Using Alternative Perceptions of Consumption Adequacy”, Review of Economics and Statistics, 82, 462 - 471.

Ravaillon, M., Datt, G. \& van de Wale, D. (1991) "Quantifying Absolute Poverty in the Developing World", Review of Income and Wealth, 37, 345 - 61.

Ravallion, M. and Chen, S. (2004) “China’s (Uneven) Progress Against Poverty”, World Bank Policy Research Working Paper 3408.

Riskin, Carl (1994) “Chinese Rural Poverty: Marginalized or Dispersed?”, American Economic Review, 84 (2), 281 - 284.

Saunders, P, Halleröd, B. and Matheson, G. (1994) "Making Eands Meet in Australia and Sweden - A Comparative Analysis Using the Subjective Poverty Line Methodology, Acta Sociologica, 37 (1) $3-22$.

van Praag, Bernard M. S., Hagenaars, Aldi J.M and van Weeren, Hans (1982) "Poverty in Europe”, Review of Income and Wealth, 28, 345 - 359.

Yao, S. (2000) "Economic Development and Poverty Reduction in China over 20 Years of Reform”, Economic Development and Cultural Change, 48, 447 - 474. 
Table 1: Estimates of Response Functions

\begin{tabular}{|c|c|c|c|}
\hline $\begin{array}{l}\text { Explained variables } \\
\text { Explanatory Variables }\end{array}$ & $\begin{array}{l}\text { Grain in } \\
\text { physical unit }\end{array}$ & Grain in cash & Cash \\
\hline Log household income & $\begin{array}{l}0.01824 \\
(2.00)^{* *}\end{array}$ & $\begin{array}{l}0.02429 \\
(2.44)^{* *}\end{array}$ & $\begin{array}{r}0.14891 \\
(9.80)^{* * *}\end{array}$ \\
\hline Dummy of households of single family member & $\begin{array}{r}-0.99653 \\
(10.91)^{* * *}\end{array}$ & $\begin{array}{r}-0.95644 \\
(9.58) * * *\end{array}$ & $\begin{array}{r}-0.83509 \\
(5.48)^{* * *}\end{array}$ \\
\hline Dummy of households of 2 family members & $\begin{array}{r}-0.59956 \\
(27.01)^{* * *}\end{array}$ & $\begin{array}{r}-0.59478 \\
(24.52)^{* * *}\end{array}$ & $\begin{array}{r}-0.41945 \\
(11.34)^{* * *}\end{array}$ \\
\hline Dummy of households of 3 family members & $\begin{array}{r}-0.27322 \\
(19.41)^{* * *}\end{array}$ & $\begin{array}{r}-0.28287 \\
(18.39)^{* * *}\end{array}$ & $\begin{array}{r}-0.19711 \\
(8.40)^{* * *}\end{array}$ \\
\hline Dummy of households of 5 family members & $\begin{array}{r}0.20958 \\
(14.80)^{* * *}\end{array}$ & $\begin{array}{r}0.21196 \\
(13.69) * * *\end{array}$ & $\begin{array}{r}0.08416 \\
(3.56)^{* * *}\end{array}$ \\
\hline Dummy of households of 6 family members & $\begin{array}{r}0.38681 \\
(19.21)^{* * *}\end{array}$ & $\begin{array}{r}0.42054 \\
(19.11)^{* * *}\end{array}$ & $\begin{array}{r}0.17105 \\
(5.09)^{* * *}\end{array}$ \\
\hline Dummy of households of 7 family members & $\begin{array}{r}0.53176 \\
(17.33)^{* * *}\end{array}$ & $\begin{array}{r}0.54073 \\
(16.12)^{* * *}\end{array}$ & $\begin{array}{r}0.27257 \\
(5.33)^{* * *}\end{array}$ \\
\hline Dummy of households of 8 family members & $\begin{array}{r}0.75201 \\
(16.26)^{* * *}\end{array}$ & $\begin{array}{r}0.74346 \\
(14.71)^{* * *}\end{array}$ & $\begin{array}{r}0.32351 \\
(4.19)^{* * *}\end{array}$ \\
\hline Number of pre-school children & $\begin{array}{c}-0.04772 \\
(3.71)^{* * *}\end{array}$ & $\begin{array}{r}-0.04191 \\
(2.99)^{* * *}\end{array}$ & $\begin{array}{r}-0.04096 \\
(1.91)^{*}\end{array}$ \\
\hline Number of school children & $\begin{array}{r}-0.00547 \\
(0.84)\end{array}$ & $\begin{array}{r}0.00906 \\
(1.28)\end{array}$ & $\begin{array}{r}0.08472 \\
(7.83)^{* * *}\end{array}$ \\
\hline Number of elderly & $\begin{array}{r}0.00001 \\
(0.00)\end{array}$ & $\begin{array}{r}0.00587 \\
(0.64)\end{array}$ & $\begin{array}{r}-0.01338 \\
(0.95)\end{array}$ \\
\hline Dummy of minority households & $\begin{array}{r}-0.02235 \\
(1.53)\end{array}$ & $\begin{array}{r}-0.01081 \\
(0.68)\end{array}$ & $\begin{array}{r}0.10148 \\
(4.18)^{* * *}\end{array}$ \\
\hline Log county income per capita & $\begin{array}{r}-0.10146 \\
(6.73)^{* * *}\end{array}$ & $\begin{array}{r}-0.04388 \\
(2.66)^{* * *}\end{array}$ & $\begin{array}{r}0.30760 \\
(12.24)^{* * *}\end{array}$ \\
\hline Constant & $\begin{array}{r}7.40251 \\
(73.76)^{* * *}\end{array}$ & $\begin{array}{r}6.92636 \\
(63.15)^{* * *}\end{array}$ & $\begin{array}{r}4.70806 \\
(28.14)^{* * *}\end{array}$ \\
\hline Number of Observations & 6853 & 6853 & 6853 \\
\hline R-squared & 0.34 & 0.31 & 0.15 \\
\hline
\end{tabular}

Absolute value of $t$ statistics in parentheses

* Significant at 10\%; ** significant at 5\%; *** significant at $1 \%$

Source: 2002 Household Income Survey 
Table 2: Poverty lines by number of adult household members and percentile of county income per capita

\begin{tabular}{|c|c|c|c|c|c|c|c|c|}
\hline \multirow{2}{*}{$\begin{array}{c}\text { Number of } \\
\text { adult } \\
\text { household } \\
\text { members }\end{array}$} & \multicolumn{8}{|c|}{ Percentile and mean of country income per capita } \\
\hline & $5 \%$ & $10 \%$ & $25 \%$ & $50 \%$ & $75 \%$ & $90 \%$ & $95 \%$ & Mean \\
\hline \multicolumn{9}{|c|}{ (Grain in physical unit. Kilogram) } \\
\hline 1 & 324 & 320 & 313 & 303 & 296 & 287 & 277 & 300 \\
\hline 2 & 243 & 240 & 234 & 227 & 221 & 215 & 208 & 225 \\
\hline 3 & 226 & 223 & 218 & 211 & 206 & 200 & 193 & 209 \\
\hline 4 & 223 & 221 & 216 & 209 & 204 & 198 & 191 & 207 \\
\hline 5 & 221 & 219 & 214 & 207 & 202 & 196 & 189 & 205 \\
\hline 6 & 221 & 218 & 213 & 207 & 202 & 195 & 189 & 205 \\
\hline 7 & 219 & 217 & 212 & 206 & 200 & 194 & 188 & 203 \\
\hline 8 & 240 & 237 & 232 & 225 & 219 & 213 & 206 & 222 \\
\hline \multicolumn{9}{|c|}{ (Grain in cash unit. Yuan) } \\
\hline 1 & 328 & 327 & 323 & 319 & 316 & 311 & 307 & 318 \\
\hline 2 & 238 & 237 & 234 & 231 & 229 & 226 & 222 & 230 \\
\hline 3 & 218 & 217 & 215 & 212 & 210 & 207 & 204 & 211 \\
\hline 4 & 219 & 218 & 216 & 213 & 210 & 208 & 205 & 212 \\
\hline 5 & 218 & 216 & 214 & 211 & 209 & 206 & 203 & 210 \\
\hline 6 & 225 & 223 & 221 & 218 & 216 & 213 & 210 & 217 \\
\hline 7 & 218 & 217 & 214 & 212 & 209 & 206 & 203 & 211 \\
\hline 8 & 234 & 233 & 231 & 228 & 225 & 222 & 219 & 227 \\
\hline \multicolumn{9}{|c|}{ (Cash. Unit: Yuan) } \\
\hline 1 & 1280 & 1336 & 1449 & 1609 & 1762 & 1963 & 2207 & 1676 \\
\hline 2 & 1043 & 1088 & 1180 & 1311 & 1436 & 1600 & 1798 & 1366 \\
\hline 3 & 903 & 942 & 1022 & 1135 & 1243 & 1385 & 1557 & 1182 \\
\hline 4 & 854 & 891 & 966 & 1073 & 1175 & 1309 & 1472 & 1118 \\
\hline 5 & 754 & 787 & 853 & 948 & 1038 & 1156 & 1300 & 987 \\
\hline 6 & 696 & 726 & 787 & 875 & 958 & 1067 & 1200 & 911 \\
\hline 7 & 672 & 701 & 760 & 845 & 925 & 1031 & 1158 & 880 \\
\hline 8 & 624 & 651 & 706 & 785 & 859 & 957 & 1076 & 817 \\
\hline \multicolumn{9}{|c|}{ (Grain in cash + cash. Unit: Yuan) } \\
\hline 1 & 1608 & 1663 & 1772 & 1928 & 2078 & 2274 & 2514 & 1994 \\
\hline 2 & 1281 & 1325 & 1414 & 1542 & 1665 & 1826 & 2020 & 1596 \\
\hline 3 & 1121 & 1159 & 1237 & 1347 & 1453 & 1592 & 1761 & 1393 \\
\hline 4 & 1073 & 1109 & 1182 & 1286 & 1385 & 1517 & 1677 & 1330 \\
\hline 5 & 972 & 1003 & 1067 & 1159 & 1247 & 1362 & 1503 & 1197 \\
\hline 6 & 921 & 949 & 1008 & 1093 & 1174 & 1280 & 1410 & 1128 \\
\hline 7 & 890 & 918 & 974 & 1057 & 1134 & 1237 & 1361 & 1091 \\
\hline 8 & 858 & 884 & 937 & 1013 & 1084 & 1179 & 1295 & 1044 \\
\hline
\end{tabular}

Source: Table 1 and 2002 Household Income Survey 
Table 3 Equivalence scale for rural China and its components as implied in the response function

\begin{tabular}{c|ccc|ccc}
\hline \multirow{2}{*}{$\begin{array}{c}\text { Number of adult } \\
\text { household } \\
\text { members (S) }\end{array}$} & \multicolumn{3}{|c|}{ Equivalence Scale (N) } & \multicolumn{2}{c}{$\begin{array}{c}\text { Marginal change in expenditure needs } \\
\text { (in proportion of needs for single person } \\
\text { household) }\end{array}$} \\
\cline { 2 - 7 } & $\begin{array}{c}\text { Grain in } \\
\text { cash }\end{array}$ & Cash & $\begin{array}{c}\text { Grain in } \\
\text { cash + cash }\end{array}$ & $\begin{array}{c}\text { Grain in } \\
\text { cash }\end{array}$ & Cash & $\begin{array}{c}\text { Grain in } \\
\text { cash + cash }\end{array}$ \\
\hline 1 & 1.00 & 1.00 & 1.00 & - & - & - \\
2 & 1.72 & 1.81 & 1.80 & 0.72 & 0.81 & 0.80 \\
3 & 2.39 & 2.52 & 2.50 & 0.67 & 0.71 & 0.70 \\
4 & 3.06 & 3.19 & 3.17 & 0.67 & 0.67 & 0.67 \\
5 & 3.72 & 3.78 & 3.77 & 0.66 & 0.59 & 0.60 \\
6 & 4.40 & 4.32 & 4.33 & 0.68 & 0.54 & 0.56 \\
7 & 5.07 & 4.86 & 4.88 & 0.67 & 0.54 & 0.55 \\
8 & 5.78 & 5.33 & 5.41 & 0.71 & 0.57 & 0.53
\end{tabular}

Note: the equivalence scale in this table is based on poverty lines derived for a countyiwth median percapita income as reported in Table 2. Equivalence scales based on other percentiles (and the mean) of county income per capita are rather similar.

Source: Table 2. 
Table 4: Poverty Lines by Province for rural China 2002

(Unit: Kilogram for Grain in physical unit and Yuan for all other categories)

\begin{tabular}{l|ccccc}
\hline \multicolumn{1}{c|}{ Province } & $\begin{array}{c}\text { (1) Grain in } \\
\text { physical } \\
\text { unit }\end{array}$ & $\begin{array}{c}\text { (2) Grain in } \\
\text { cash }\end{array}$ & (3) Cash & $\begin{array}{c}\text { (4) Total } \\
\text { poverty line } \\
(=(2)+(3))\end{array}$ & $\begin{array}{c}\text { (5) Mean } \\
\text { income of } \\
\text { province }\end{array}$ \\
\hline Beijing & 195 & 207 & 1,419 & 1,626 & 5,383 \\
Hebei & 207 & 213 & 1,057 & 1,271 & 2,910 \\
Shanxi & 211 & 215 & 1,007 & 1,221 & 2,292 \\
Liaoning & 206 & 212 & 1,165 & 1,376 & 2,806 \\
Jilin & 210 & 214 & 1,078 & 1,292 & 2,664 \\
Jiangsu & 201 & 210 & 1,249 & 1,459 & 4,649 \\
Zhejiang & 190 & 205 & 1,536 & 1,741 & 6,320 \\
Anhui & 213 & 215 & 948 & 1,163 & 2,189 \\
Jiangxi & 209 & 214 & 996 & 1,210 & 2,446 \\
Shandong & 203 & 211 & 1,188 & 1,399 & 3,323 \\
Henan & 210 & 214 & 999 & 1,213 & 2,426 \\
Hubei & 209 & 214 & 1,039 & 1,253 & 2,626 \\
Hunan & 206 & 212 & 1,085 & 1,297 & 2,688 \\
Guangdong & 198 & 209 & 1,167 & 1,377 & 4,548 \\
Guangxi & 216 & 218 & 852 & 1,070 & 1,861 \\
Chongqing & 213 & 215 & 1,057 & 1,272 & 2,400 \\
Sichuan & 212 & 214 & 1,040 & 1,255 & 2,422 \\
Guizhou & 222 & 220 & 797 & 1,016 & 1,495 \\
Yunnan & 217 & 218 & 850 & 1,068 & 1,697 \\
Shaanxi & 219 & 218 & 843 & 1,062 & 1,779 \\
Gansu & 219 & 219 & 820 & 1,039 & 1,833 \\
Xinjiang & 214 & 218 & 896 & 1,114 & 2,366 \\
\hline China as a whole & 209 & 214 & 1,035 & 1,249 & 2,812 \\
\hline
\end{tabular}

Note: poverty lines shown in columns (1), (2), and (3) for each province are derived as mean of poverty lines for households of different family sizes. Further, county income is set to the median of that province. The poverty lines for China as a whole are simply obtained by averaging poverty lines in per capita terms over the total sample households.

Source: Table 1 and 2002 Household Income Survey. 
Table 5: Poverty indices and their decompositions by various household attributes

\begin{tabular}{|c|c|c|c|c|c|c|c|}
\hline & \multirow[b]{2}{*}{$\begin{array}{l}\text { Number of } \\
\text { individuals }\end{array}$} & \multicolumn{3}{|c|}{ Poverty index } & \multicolumn{3}{|c|}{ Decomposition of poverty index } \\
\hline & & Headcount & $\begin{array}{l}\text { Poverty } \\
\text { gap }\end{array}$ & $\begin{array}{l}\text { Poverty } \\
\text { gap } \\
\text { squared }\end{array}$ & Headcount & $\begin{array}{l}\text { Poverty } \\
\text { gap }\end{array}$ & $\begin{array}{l}\text { Poverty } \\
\text { gap } \\
\text { squared }\end{array}$ \\
\hline \multicolumn{8}{|l|}{ By province } \\
\hline Beijing & 563 & 3.91 & 1.01 & 0.56 & 0.38 & 0.35 & 0.42 \\
\hline Hebei & 1,511 & 19.85 & 5.73 & 2.42 & 5.22 & 5.36 & 4.87 \\
\hline Shanxi & 1,622 & 21.27 & 8.27 & 5.03 & 6.00 & 8.30 & 10.88 \\
\hline Liaoning & 1,583 & 20.47 & 6.48 & 3.11 & 5.63 & 6.35 & 6.55 \\
\hline Jilin & 1,763 & 13.78 & 4.92 & 3.82 & 4.22 & 5.37 & 8.96 \\
\hline Jiangsu & 1,583 & 3.47 & 0.87 & 0.33 & 0.96 & 0.86 & 0.71 \\
\hline Zhejiang & 1,924 & 10.86 & 4.94 & 3.06 & 3.63 & 5.89 & 7.83 \\
\hline Anhui & 1,836 & 14.00 & 2.86 & 0.93 & 4.47 & 3.25 & 2.27 \\
\hline Jiangxi & 1,890 & 10.95 & 3.29 & 1.22 & 3.60 & 3.85 & 3.07 \\
\hline Shandong & 2,343 & 11.22 & 3.34 & 1.95 & 4.57 & 4.84 & 6.07 \\
\hline Henan & 2,219 & 10.46 & 2.10 & 0.71 & 4.03 & 2.89 & 2.10 \\
\hline Hubei & 2,093 & 12.57 & 3.14 & 1.35 & 4.57 & 4.06 & 3.76 \\
\hline Hunan & 1,848 & 20.83 & 5.10 & 1.79 & 6.69 & 5.83 & 4.40 \\
\hline Guangdong & 2,463 & 2.92 & 0.79 & 0.40 & 1.25 & 1.20 & 1.30 \\
\hline Guangxi & 1,928 & 12.34 & 2.60 & 0.78 & 4.14 & 3.10 & 2.00 \\
\hline Chongqing & 677 & 12.26 & 2.11 & 0.59 & 1.44 & 0.89 & 0.53 \\
\hline Sichuan & 1,832 & 12.01 & 2.55 & 0.90 & 3.82 & 2.89 & 2.20 \\
\hline Guizhou & 1,798 & 33.43 & 8.06 & 2.85 & 10.45 & 8.96 & 6.82 \\
\hline Yunnan & 1,199 & 23.77 & 9.52 & 5.30 & 4.95 & 7.06 & 8.46 \\
\hline Shaanxi & 1,641 & 26.39 & 7.15 & 3.06 & 7.53 & 7.26 & 6.69 \\
\hline Gansu & 1,439 & 29.95 & 7.29 & 2.75 & 7.49 & 6.49 & 5.27 \\
\hline Xinjiang & 1,834 & 15.49 & 4.37 & 1.98 & 4.94 & 4.96 & 4.84 \\
\hline Total sample & 37,589 & 15.30 & 4.30 & 2.00 & 100.00 & 100.00 & 100.00 \\
\hline \multicolumn{8}{|c|}{ (Decomposition using true population weight) } \\
\hline \multicolumn{8}{|l|}{ By region } \\
\hline West & 31.95 & 20.85 & 5.45 & 2.24 & 43.83 & 40.66 & 35.89 \\
\hline Central & 35.11 & 14.56 & 4.08 & 2.01 & 33.63 & 33.52 & 35.33 \\
\hline East & 32.94 & 10.40 & 3.35 & 1.74 & 22.54 & 25.82 & 28.78 \\
\hline Total sample & 100.00 & 15.20 & 4.28 & 1.99 & 100.00 & 100.00 & 100.00 \\
\hline \multicolumn{8}{|c|}{ By poor county and non-poor county } \\
\hline Non-poor county & 78.51 & 10.42 & 3.06 & 1.58 & 55.37 & 57.75 & 63.70 \\
\hline Poor county & 21.49 & 30.68 & 8.19 & 3.30 & 44.63 & 42.25 & 36.30 \\
\hline Total sample & 100.00 & 14.77 & 4.16 & 1.95 & 100.00 & 100.00 & 100.00 \\
\hline \multicolumn{8}{|l|}{ By ethnic status } \\
\hline Non-minority & 91.59 & 14.37 & 4.07 & 1.93 & 88.31 & 88.72 & 89.86 \\
\hline Minority & 8.41 & 20.72 & 5.63 & 2.38 & 11.69 & 11.28 & 10.14 \\
\hline
\end{tabular}


Note: The number of individuals in the sample are: western region 12 348, central region 13 271, eastern region 11 970; non-poor counties 28 573, poor counties 9 062; non- minorities 32 059, minorities 5530.

Source: 2002 Household Income Survey and 2000 Census. 
Table 6: Poverty indices and their decompositions by various demographical household attributes

\begin{tabular}{|c|c|c|c|c|c|c|c|}
\hline & \multirow[b]{2}{*}{$\begin{array}{l}\text { The number } \\
\text { of individuals }\end{array}$} & \multicolumn{3}{|c|}{ Poverty index } & \multicolumn{3}{|c|}{ Decomposition of poverty index } \\
\hline & & $\begin{array}{c}\text { Headcoun } \\
t\end{array}$ & $\begin{array}{l}\text { Poverty } \\
\text { gap }\end{array}$ & $\begin{array}{l}\text { Poverty } \\
\text { gap } \\
\text { squared }\end{array}$ & Headcount & $\begin{array}{l}\text { Poverty } \\
\text { gap }\end{array}$ & $\begin{array}{l}\text { Poverty } \\
\text { gap } \\
\text { squared }\end{array}$ \\
\hline \multicolumn{8}{|c|}{ By the age of household members } \\
\hline$<=7$ & 2,141 & 22.05 & 6.67 & 3.21 & 8.21 & 8.83 & 9.15 \\
\hline $8-13$ & 3,709 & 18.41 & 4.98 & 2.38 & 11.87 & 11.42 & 11.77 \\
\hline $14-18$ & 4,704 & 13.92 & 3.87 & 1.69 & 11.39 & 11.27 & 10.59 \\
\hline $19-25$ & 4,904 & 12.50 & 3.42 & 1.50 & 10.66 & 10.37 & 9.78 \\
\hline 26-35 & 5,328 & 17.87 & 5.25 & 2.64 & 16.55 & 17.30 & 18.76 \\
\hline $36-45$ & 6,192 & 13.95 & 3.82 & 1.75 & 15.02 & 14.65 & 14.47 \\
\hline $46-55$ & 6,123 & 12.33 & 3.30 & 1.39 & 13.13 & 12.49 & 11.30 \\
\hline$>=56$ & 4,488 & 16.89 & 4.92 & 2.37 & 13.18 & 13.67 & 14.17 \\
\hline Total sample & 37,589 & 15.30 & 4.30 & 2.00 & 100.00 & 100.00 & 100.00 \\
\hline \multicolumn{8}{|c|}{ By number of household member } \\
\hline 1 & 24 & 29.17 & 7.44 & 2.91 & 0.12 & 0.11 & 0.09 \\
\hline 2 & 1,452 & 14.19 & 4.60 & 2.78 & 3.58 & 4.14 & 5.37 \\
\hline 3 & 6,606 & 10.22 & 3.02 & 1.78 & 11.74 & 12.35 & 15.69 \\
\hline 4 & 12,336 & 15.66 & 4.47 & 2.04 & 33.59 & 34.13 & 33.50 \\
\hline 5 & 9,810 & 17.02 & 4.86 & 2.18 & 29.03 & 29.52 & 28.42 \\
\hline 6 & 4,812 & 17.83 & 4.33 & 1.65 & 14.92 & 12.89 & 10.58 \\
\hline 7 & 1,925 & 16.00 & 4.65 & 2.08 & 5.35 & 5.54 & 5.33 \\
\hline 8 & 624 & 15.38 & 3.41 & 1.23 & 1.67 & 1.32 & 1.02 \\
\hline Total sample & 37,589 & 15.30 & 4.30 & 2.00 & 100.00 & 100.00 & 100.00 \\
\hline \multicolumn{8}{|c|}{ By education attainment of the head of household* } \\
\hline 1 & 3,194 & 17.09 & 5.55 & 2.50 & 9.49 & 10.97 & 10.64 \\
\hline 2 & 9,523 & 19.58 & 5.50 & 2.43 & 32.42 & 32.41 & 30.77 \\
\hline 3 & 17,799 & 14.53 & 3.93 & 1.84 & 44.98 & 43.24 & 43.57 \\
\hline 4 & 6,758 & 11.10 & 3.17 & 1.65 & 13.04 & 13.25 & 14.88 \\
\hline 5 & 315 & 1.27 & 0.67 & 0.36 & 0.07 & 0.13 & 0.15 \\
\hline Total sample & 37,589 & 15.30 & 4.30 & 2.00 & 100.00 & 100.00 & 100.00 \\
\hline
\end{tabular}

Note: * Meanings of educational categories are as follows. 1: Illiterate or semi-illiterate, and 1-3 years of elementary school; 2: More years of elementary school; 3: Junior middle school; 4: Senior middle school and middle level professional, and technical or vocational school; 5: Professional school, college, and above.

Source: 2002 Household Income Survey. 
Table 7: Estimated results of Probit model of determinants of poverty status

\begin{tabular}{|c|c|c|c|}
\hline Explanatory variables & Specification 1 & Specification 2 & Specification 3 \\
\hline Age of family member & $\begin{array}{r}-0.13111 \\
(7.14)^{* * *}\end{array}$ & $\begin{array}{r}-0.13023 \\
(7.14)^{* * *}\end{array}$ & $\begin{array}{r}-0.12926 \\
(6.98)^{* * *}\end{array}$ \\
\hline Squared age of family number & $\begin{array}{r}0.01209 \\
(6.29)^{* * *}\end{array}$ & $\begin{array}{r}0.01230 \\
(6.44)^{* * *}\end{array}$ & $\begin{array}{r}0.01220 \\
(6.30)^{* * *}\end{array}$ \\
\hline Education years of the head of household & $\begin{array}{r}-0.11718 \\
(11.94)^{* * *}\end{array}$ & $\begin{array}{r}-0.10737 \\
(11.32)^{* * *}\end{array}$ & $\begin{array}{r}-0.09361 \\
(9.74)^{* * *}\end{array}$ \\
\hline The number of family members & $\begin{array}{r}0.03667 \\
(5.31)^{* * *}\end{array}$ & $\begin{array}{r}0.01952 \\
(2.97)^{* * *}\end{array}$ & $\begin{array}{r}0.00979 \\
(1.46)\end{array}$ \\
\hline Minority dummy & $\begin{array}{r}0.04341 \\
(1.48)\end{array}$ & $\begin{array}{c}-0.05243 \\
(2.32)^{* *}\end{array}$ & $\begin{array}{r}-0.08241 \\
(3.60)^{* * *}\end{array}$ \\
\hline (Provincial dummy) & & & \\
\hline Hebei & $\begin{array}{r}0.89785 \\
(8.66)^{* * *}\end{array}$ & & \\
\hline Shanxi & $\begin{array}{r}0.91647 \\
(8.89)^{* * *}\end{array}$ & & \\
\hline Liaoning & $\begin{array}{r}0.89373 \\
(8.60)^{* * *}\end{array}$ & & \\
\hline Jilin & $\begin{array}{r}0.63531 \\
(6.12)^{* * *}\end{array}$ & & \\
\hline Jiangsu & $\begin{array}{r}-0.09332 \\
(0.82)\end{array}$ & & \\
\hline Zhejiang & $\begin{array}{r}0.46644 \\
(4.48)^{* * *}\end{array}$ & & \\
\hline Anhui & $\begin{array}{r}0.60382 \\
(5.83)^{* * *}\end{array}$ & & \\
\hline Jiangxi & $\begin{array}{r}0.43454 \\
(4.16)^{* * *}\end{array}$ & & \\
\hline Shangdong & $\begin{array}{r}0.54023 \\
(5.26)^{* * *}\end{array}$ & & \\
\hline Henan & $\begin{array}{r}0.46944 \\
(4.55)^{* * *}\end{array}$ & & \\
\hline Hubei & $\begin{array}{r}0.57190 \\
(5.55)^{* * *}\end{array}$ & & \\
\hline Hunan & $\begin{array}{r}0.87452 \\
(8.53)^{* * *}\end{array}$ & & \\
\hline Guangdong & $\begin{array}{r}-0.20227 \\
(1.84)^{*}\end{array}$ & & \\
\hline Guangxi & $\begin{array}{r}0.47951 \\
(4.58)^{* * *}\end{array}$ & & \\
\hline Chongqing & $\begin{array}{r}0.54635 \\
(4.75)^{* * *}\end{array}$ & & \\
\hline Sichuan & $\begin{array}{r}0.51560 \\
(4.95)^{* * *}\end{array}$ & & \\
\hline Guizhou & $\begin{array}{r}1.17854 \\
(11.47)^{* * *}\end{array}$ & & \\
\hline Yuanan & $\begin{array}{r}0.90084 \\
(8.47)^{* * *}\end{array}$ & & \\
\hline Shaanxi & $\begin{array}{r}1.07093 \\
(10.45)^{* * *}\end{array}$ & & \\
\hline Gansu & $\begin{array}{r}1.15939 \\
(11.24)^{* * *}\end{array}$ & & \\
\hline
\end{tabular}




\begin{tabular}{|c|c|c|c|}
\hline Xinjiang & $\begin{aligned} 0.54647 \\
\end{aligned}$ & & \\
\hline Provincial Gini coefficient & & $\begin{array}{r}5.89539 \\
(0) 89) * * *\end{array}$ & $\begin{array}{r}5.54659 \\
(21.38) * * *\end{array}$ \\
\hline Log provincial income per capita & & $\begin{array}{r}-1.01613 \\
(34.69)^{* * *}\end{array}$ & $\begin{array}{l}-0.64603 \\
(20.57)^{* * *}\end{array}$ \\
\hline Poor-country dummy & & & $\begin{array}{r}0.61323 \\
(31.66)^{* * *}\end{array}$ \\
\hline Constant & $\begin{array}{r}-1.24427 \\
(11.09)^{* * *}\end{array}$ & $\begin{array}{r}5.57277 \\
(26.17)^{* * *}\end{array}$ & $\begin{array}{r}2.59941 \\
(11.21)^{* * *}\end{array}$ \\
\hline Observations & 37589 & 37589 & 37589 \\
\hline
\end{tabular}

Note: Individuals are the unit of observation;

Absolute value of $\mathrm{z}$ statistics is given in parentheses.

* Significant at 10\%; ** significant at 5\%; *** significant at $1 \%$.

Source: 2002 Household Income Survey 
Figure 1:

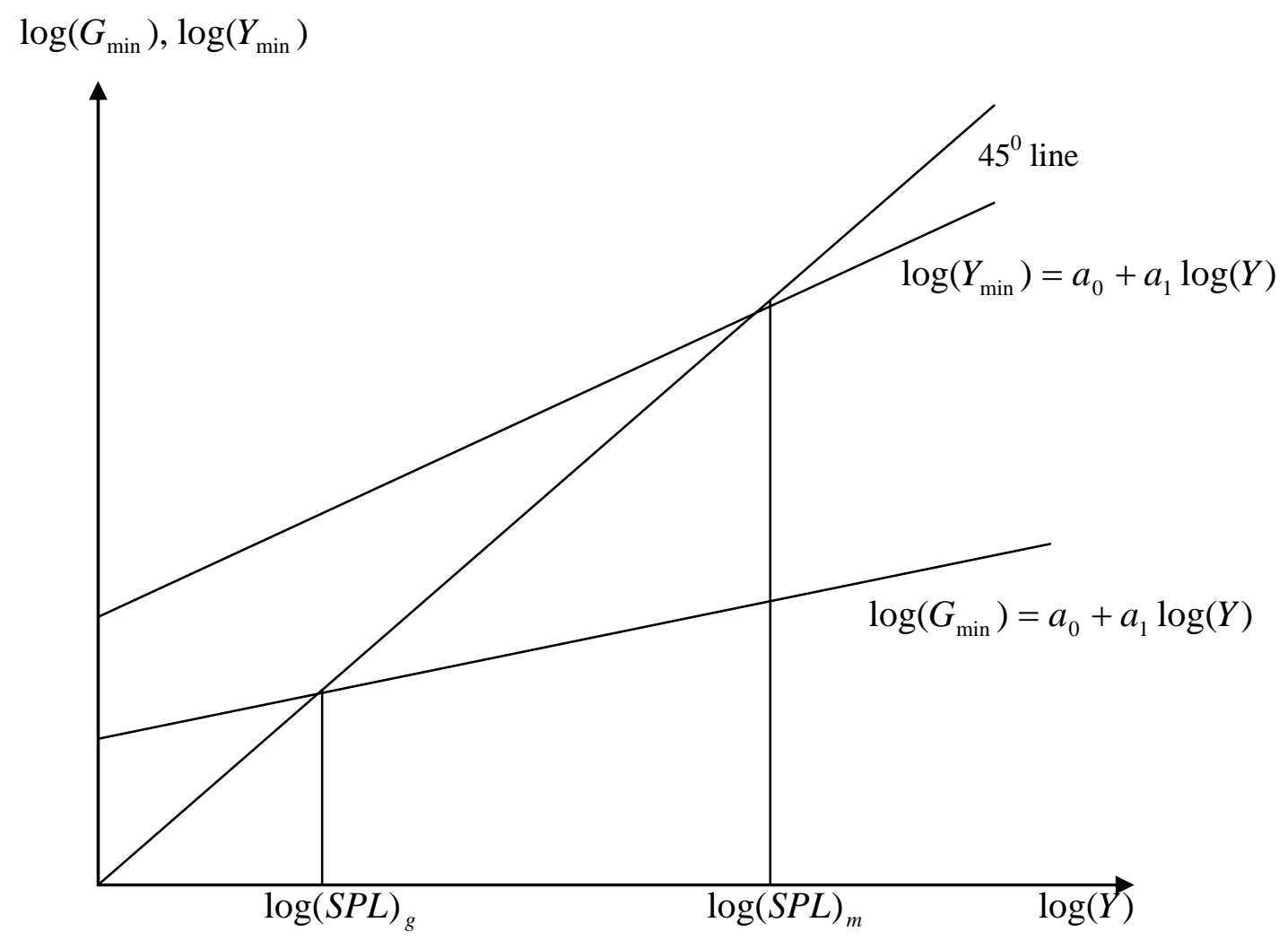

Figure 2: Predicted Probability of Being Poor for Two Types of Households across Provinces

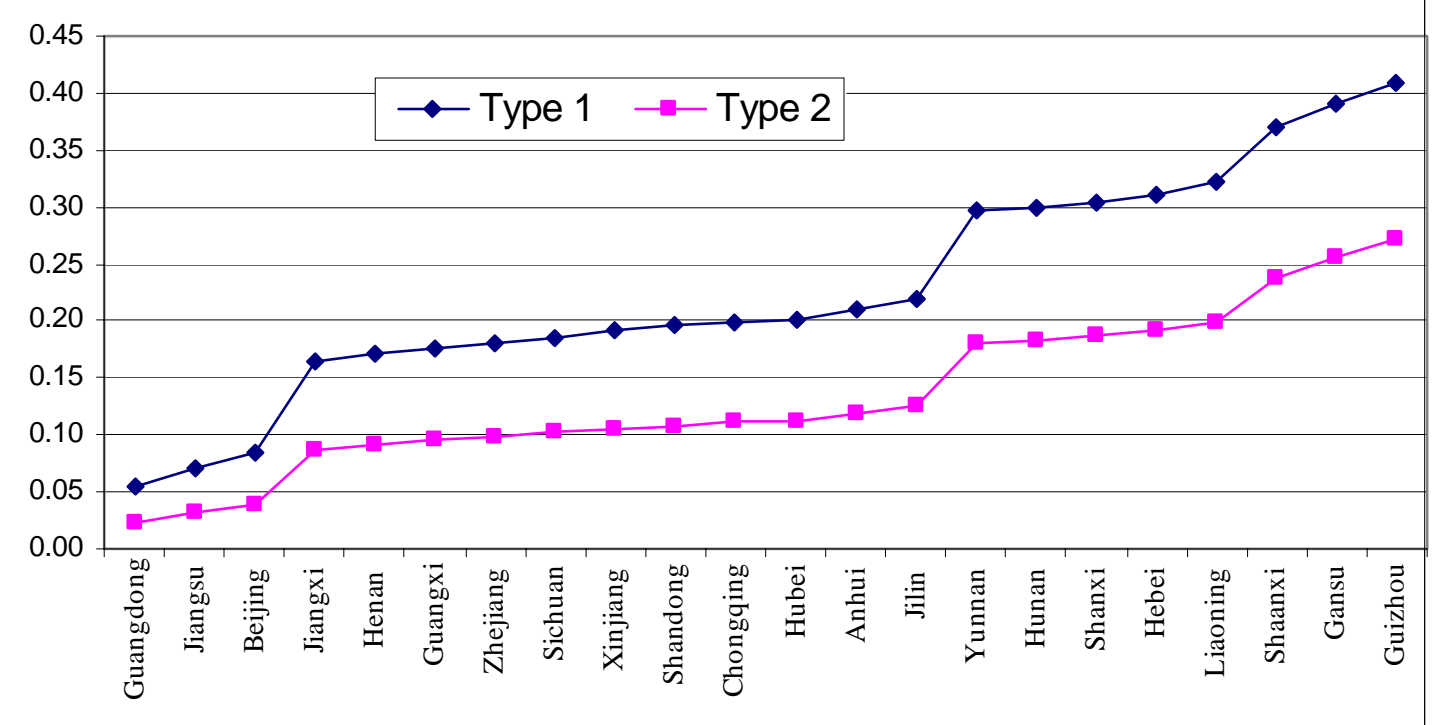

Note: Type 1 household has 6 family members and is led by a head aged 30 with 6 years of education. Type 2 household has 5 family members and is led by a head aged 50 with 9 years of education. 


\section{Appendix 1: The transformation of perceived minimum needs for grain in physical units into cash.}

In the survey which creates data used in this study, questions about minimum need for grain and for cash were asked separately. When asking the minimum requirement for grain, respondents answered by providing a number in kilograms, rather than in a monetary unit. This was done because most grain consumed in rural areas in China is self-produced and there are no transactions and prices involved in daily life. Therefore, the question of a minimum requirement for grain is most probably answered more accurately in physical units rather than in monetary units.

In deriving a poverty line that contains minimum needs of both grain and cash, we need to convert grain from a physical unit into a monetary unit, thus a grain price is necessary. In the survey there is no question regarding grain price for the responding household to answer. However, in an accompanying village questionnaire completed by village cadres there is information on procurement price of grain; this is a price determined by the government for buying grain if market prices fall below this price. The purpose of this system is to protect the market price of grain from falling so much that it would have an adverse impact on peasants' income and incentives for growing grain.

Prices for three types of grain (rice, wheat and corn) as well as their yields are asked for in the village questionnaires given to 961 villages. A weighted average of the three prices for each village with their yields as weight, is used to convert the grain from a physical unit into a monetary unit. The simple mean of the grain prices over all villages is 1.0079 Yuan per kilogram. An important question here is how close is this price to the market price of grain?

Market prices of the three types of grain for China as a whole available from China Agricultural Product Price Survey Yearbook 2004, combined with yields of corresponding grain from China Statistical Yearbook 2003, produces the number 1.0762 Yuan per kilogram of yield-weighted price. This indicates that the procurement price is very close to the market price for China as a whole and provides justification (given that more proper information is unavailable), for the use of procurement price for converting minimum requirement of grain in physical units into monetary terms. Actually, before putting the procurement price by 
village into use, we scale up them so that mean protection prices over villages equals the market price of 1.0762 Yuan per kilogram, as just mentioned. 
Appendix 2 Table 1: estimated MIQ equation with provincial dummy

\begin{tabular}{|c|c|c|c|}
\hline Explanatory variables & $\begin{array}{c}\text { Grain in } \\
\text { physical unit }\end{array}$ & Grain in cash & Cash \\
\hline Log household income & $\begin{array}{c}0.00883 \\
(1.02)\end{array}$ & $\begin{array}{c}0.01087 \\
(1.17)\end{array}$ & $\begin{array}{c}0.15557 \\
(10.99)^{* * *}\end{array}$ \\
\hline Dummy of households of single family member & $\begin{array}{c}-0.94724 \\
(10.98)^{* * *}\end{array}$ & $\begin{array}{l}-0.88944 \\
(9.62)^{* * *}\end{array}$ & $\begin{array}{c}-0.93651 \\
(6.63)^{* * *}\end{array}$ \\
\hline Dummy of households of 2 family members & $\begin{array}{c}-0.56537 \\
(26.86)^{* * *}\end{array}$ & $\begin{array}{c}-0.55256 \\
(24.50)^{* * *}\end{array}$ & $\begin{array}{c}-0.40622 \\
(11.78)^{* * *}\end{array}$ \\
\hline Dummy of households of 3 family members & $\begin{array}{c}-0.25314 \\
(18.84)^{* * *}\end{array}$ & $\begin{array}{c}-0.25277 \\
(17.55)^{* * *}\end{array}$ & $\begin{array}{c}-0.17093 \\
(7.77)^{* * *}\end{array}$ \\
\hline Dummy of households of 5 family members & $\begin{array}{c}0.21147 \\
(15.78)^{* * *}\end{array}$ & $\begin{array}{c}0.20888 \\
(14.54)^{* * *}\end{array}$ & $\begin{array}{c}0.06249 \\
(2.85)^{* * *}\end{array}$ \\
\hline Dummy of households of 6 family members & $\begin{array}{c}0.38638 \\
(20.19)^{* * *}\end{array}$ & $\begin{array}{c}0.40506 \\
(19.75)^{* * *}\end{array}$ & $\begin{array}{c}0.14431 \\
(4.60)^{* * *}\end{array}$ \\
\hline Dummy of households of 7 family members & $\begin{array}{c}0.52342 \\
(17.88)^{* * *}\end{array}$ & $\begin{array}{c}0.50840 \\
(16.20)^{* * *}\end{array}$ & $\begin{array}{c}0.22719 \\
(4.74)^{* * *}\end{array}$ \\
\hline Dummy of households of 8 family members & $\begin{array}{c}0.73880 \\
(16.70)^{* * *}\end{array}$ & $\begin{array}{c}0.70820 \\
(14.93)^{* * *}\end{array}$ & $\begin{array}{c}0.26541 \\
(3.66)^{* * *}\end{array}$ \\
\hline Number of pre-school children & $\begin{array}{l}-0.05852 \\
(4.81)^{* * *}\end{array}$ & $\begin{array}{l}-0.05805 \\
(4.45)^{* * *}\end{array}$ & $\begin{array}{c}-0.03489 \\
(1.75)^{*}\end{array}$ \\
\hline Number of school children & $\begin{array}{c}0.00025 \\
(0.04)\end{array}$ & $\begin{array}{c}0.00695 \\
(1.05)\end{array}$ & $\begin{array}{c}0.08345 \\
(8.21)^{* * *}\end{array}$ \\
\hline Number of the elderly & $\begin{array}{c}-0.00023 \\
(0.03)\end{array}$ & $\begin{array}{c}0.00461 \\
(0.54)\end{array}$ & $\begin{array}{c}-0.01605 \\
(1.23)\end{array}$ \\
\hline Dummy of minority households & $\begin{array}{c}0.01238 \\
(0.64)\end{array}$ & $\begin{array}{l}0.04154 \\
(2.00)^{* *}\end{array}$ & $\begin{array}{c}0.01806 \\
(0.57)\end{array}$ \\
\hline Log county income per capita & $\begin{array}{c}-0.01079 \\
(0.54)\end{array}$ & $\begin{array}{l}0.04233 \\
(1.99)^{* *}\end{array}$ & $\begin{array}{c}0.09641 \\
(2.96)^{* * *}\end{array}$ \\
\hline (Provincial dummy) & & & \\
\hline Hebei & $\begin{array}{c}0.31352 \\
(6.33)^{* * *}\end{array}$ & $\begin{array}{c}0.42153 \\
(7.95)^{* * *}\end{array}$ & $\begin{array}{c}-0.88900 \\
(10.97)^{* * *}\end{array}$ \\
\hline Shanxi & $\begin{array}{c}0.32016 \\
(6.70)^{* * *}\end{array}$ & $\begin{array}{c}0.41010 \\
(8.01)^{* * *}\end{array}$ & $\begin{array}{c}-0.41697 \\
(5.33)^{* * *}\end{array}$ \\
\hline Liaoning & $\begin{array}{c}0.28609 \\
(6.13)^{* * *}\end{array}$ & $\begin{array}{c}0.31587 \\
(6.32)^{* * *}\end{array}$ & $\begin{array}{l}-0.47096 \\
(6.16)^{* * *}\end{array}$ \\
\hline Jilin & $\begin{array}{c}0.07344 \\
(1.57)\end{array}$ & $\begin{array}{c}-0.03897 \\
(0.78)\end{array}$ & $\begin{array}{l}-0.71680 \\
(9.35)^{* * *}\end{array}$ \\
\hline Jiangsu & $\begin{array}{c}0.40567 \\
(8.15)^{* * *}\end{array}$ & $\begin{array}{c}0.50351 \\
(9.43)^{* * *}\end{array}$ & $\begin{array}{l}-0.47545 \\
(5.83)^{* * *}\end{array}$ \\
\hline Zhejiang & $\begin{array}{c}0.34060 \\
(7.72)^{* * *}\end{array}$ & $\begin{array}{c}0.55744 \\
(11.79)^{* * *}\end{array}$ & $\begin{array}{c}-0.25011 \\
(3.46)^{* * *}\end{array}$ \\
\hline Anhui & $\begin{array}{c}0.61454 \\
(12.96)^{* * *}\end{array}$ & $\begin{array}{c}0.75712 \\
(14.90)^{* * *}\end{array}$ & $\begin{array}{c}-1.03434 \\
(13.32)^{* * *}\end{array}$ \\
\hline Jiangxi & $\begin{array}{c}0.61040 \\
(13.47)^{* * *}\end{array}$ & $\begin{array}{c}0.69268 \\
(14.26)^{* * *}\end{array}$ & $\begin{array}{l}-0.66856 \\
(9.01)^{* * *}\end{array}$ \\
\hline Shangdong & $\begin{array}{c}0.30564 \\
(7.17)^{* * *}\end{array}$ & $\begin{array}{c}0.49919 \\
(10.93)^{* * *}\end{array}$ & $\begin{array}{c}-0.86106 \\
(12.33)^{* * *}\end{array}$ \\
\hline Henan & $\begin{array}{c}0.32754 \\
(7.28)^{* * *}\end{array}$ & $\begin{array}{c}0.50593 \\
(10.50)^{* * *}\end{array}$ & $\begin{array}{c}-1.03444 \\
(14.04)^{* * *}\end{array}$ \\
\hline Hubei & $\begin{array}{c}0.40275 \\
(8.60)^{* * *}\end{array}$ & $\begin{array}{c}0.52072 \\
(10.37)^{* * *}\end{array}$ & $\begin{array}{c}-0.71124 \\
(9.27)^{* * *}\end{array}$ \\
\hline Hunan & $\begin{array}{c}0.61658 \\
(13.42)^{* * *}\end{array}$ & $\begin{array}{c}0.67590 \\
(13.72)^{* * *}\end{array}$ & $\begin{array}{l}-0.30696 \\
(4.08)^{* * *}\end{array}$ \\
\hline Guangdong & $\begin{array}{c}0.36887 \\
(8.49)^{* * *}\end{array}$ & $\begin{array}{c}0.58699 \\
(12.60)^{* * *}\end{array}$ & $\begin{array}{l}-0.14037 \\
(1.97)^{* *}\end{array}$ \\
\hline
\end{tabular}




\begin{tabular}{l|ccc} 
Guangxi & 0.30754 & 0.41309 & -0.19214 \\
Chongqing & $(5.73)^{* * *}$ & $(7.18)^{* * *}$ & $(2.19)^{* *}$ \\
& 0.48316 & 0.49075 & -0.47262 \\
Sichuan & $(8.61)^{* * *}$ & $(8.16)^{* * *}$ & $(5.14)^{* * *}$ \\
& 0.56226 & 0.62140 & -0.56184 \\
Guizhou & $(12.32)^{* * *}$ & $(12.70)^{* * *}$ & $(7.52)^{* * *}$ \\
& 0.36974 & 0.55742 & -0.87332 \\
Yuanan & $(7.44)^{* * *}$ & $(10.46)^{* * *}$ & $(10.72)^{* * *}$ \\
& 0.49569 & 0.64567 & -0.63579 \\
Shaanxi & $(9.43)^{* * *}$ & $(11.46)^{* * *}$ & $(7.39)^{* * *}$ \\
& 0.35178 & 0.48911 & -0.45244 \\
Gansu & $(7.31)^{* * *}$ & $(9.48)^{* * *}$ & $(5.74)^{* * *}$ \\
& 0.60379 & 0.84033 & -0.47636 \\
Xinjiang & $(11.94)^{* * *}$ & $(15.50)^{* * *}$ & $(5.75)^{* * *}$ \\
Constant & 0.48183 & 0.63706 & -0.76877 \\
& $(9.16)^{* * *}$ & $(11.30)^{* * *}$ & $(8.92)^{* * *}$ \\
Observations & 6.36249 & 5.83968 & 6.91494 \\
R-squared & $(39.88)^{* * *}$ & $(34.15)^{* * *}$ & $(26.46)^{* * *}$ \\
\hline
\end{tabular}

Absolute value of $\mathrm{t}$ statistics in parentheses

* significant at $10 \%$; ** significant at $5 \%$; ** significant at $1 \%$ 